\title{
Intermittent Training Followed by Detraining Provides the Preservation of Hepatic Tissue and Body Composition of Eutrophic rats in Relation to Obese Rats after the Detraining Period
}

\author{
EI Entrenamiento Intermitente Seguido de Desacondicionamiento Facilita la Preservación \\ del Tejido Hepático y la Composición Corporal de las Ratas Eutróficas en Relación a \\ las Ratas Obesas Después del Período de Desacondicionamiento
}

\begin{abstract}
Alan José Barbosa Magalhães ${ }^{1}$; Regina Celi Trindade Camargo ${ }^{2}$; Rafael Junges Moreira ${ }^{2}$; Patrícia Monteiro Seraphim²; Sergio Minoru Oikawa ${ }^{3}$ \& José Carlos Silva Camargo Filho²
\end{abstract}

MAGALHÃES, A. J. B.; CAMARGO, R. C. T.; MOREIRA, R. J.; SERAPHIM, P. M.; OIKAWA, S. M. \& CAMARGO FILHO, J. C.S. Intermittent training followed by detraining provides the preservation of hepatic tissue and body composition of eutrophic rats in relation to obese rats after the detraining period. Int. J. Morphol., 36(4):1341-1349, 2018.

SUMMARY: The aim of the study was to evaluate the effects of intermittent training followed by detraining on liver tissue and body composition of rats subjected to a normolipidic or hyperlipidic diet. Sixty Wistar rats were divided into the groups Sedentary Control (SC), Exercised Control (EC), Sedentary Control euthanized at six months of age (SC(6)), Detrained Control (DC), Sedentary Obese (SO), Exercised Obese (EO), Sedentary Obese euthanized at six months of age ( $\mathrm{SO}(6))$ and Detrained Obese (DO), which performed intermittent training for eight weeks. After, the groups SC(6), DC, SO(6) and DO performed a detraining protocol for eight weeks. The animals were euthanized, with measurements of body mass and length taken, and retrieval of Epididymal Adipose Tissue (EAT) for body composition variables and the liver for karyometric and stereological analysis. Significant differences were found in the liver mass values of the EC relative to the DO and in the $\mathrm{SO}(6)$ liver in relation to all groups, with a greater gain in body mass of the $\mathrm{SO}(6)$ in comparison to the EC; in the EAT total, EAT percentage and $\mathrm{BM}$ of $\mathrm{SO}(6)$ and $\mathrm{DO}$ in relation to the $\mathrm{EC}$ and the $\mathrm{DC}$ and in the karyometric variables of the EC and the DC in relation to EO and DO, with no differences in the stereology and on the Lee index between all groups. Intermittent training showed better effects on the DC liver tissue compared to EO and DO, and on the EC and DC body composition compared to $\mathrm{SO}(6)$ and DO.

KEY WORDS: Obesity; Liver; Body Composition; Exercise; Histology.

INTRODUCTION

The increase of body weight and excessive accumulation of lipids in adipose cells in the body, due to the ingestion of large amounts of fat and a low energy expenditure, thereby increasing the concentration of body fat, can be a factor to obesity development. Excessive consumption of a hyperlipidic diet can contribute for this process, by the high caloric values and leads fat mass increase, due to the metabolic conversion of the lipids contained in food into triglycerides, which are then stored in the adipose tissue (Assaad et al., 2014), which can be conducive to the development of obesity.

The Epididymal Adipose Tissue (EAT) has the function of storing triglycerides in its adipocytes and the gain of adipose fat can contribute to the development of the complications of obesity. Non-alcoholic Fatty Liver Disease (NAFLD) is characterized by an increase in the concentration of intrahepatic triglycerides (IHTG), which can lead to excessive tissue injury, evolving into chronic inflammation. This chronic inflammation caused by the accumulation of IHTG may result in hepatic steatosis or cirrhosis (Song et al., 2014).

Among the non-pharmacological therapeutic approaches for treating obesity and its deleterious effects on body composition and hepatic tissue, physical exercise appears as one of the most indicated to reduce body mass and the concentrations of IHTG (Spassiani \& Kuk, 2008). Intermittent training proves to be effective in reducing ab-

1 Programa de Pós Graduação em Ciências da Cirurgia, Universidade Estadual de Campinas, Campinas, Brasil.

2 Departamento de Fisioterapia, Universidade Estadual Paulista "Júlio de Mesquita Filho", São Paulo, Brasil.

3 Departamento de Estatística, Universidade Estadual Paulista "Júlio de Mesquita Filho", São Paulo, Brasil. 
MAGALHÃES, A. J. B.; CAMARGO, R. C. T.; MOREIRA, R. J.; SERAPHIM, P. M.; OIKAWA, S. M. \& CAMARGO FILHO, J. C. S. Intermittent training followed by detraining provides the preservation of hepatic tissue and body composition of eutrophic rats in relation to obese rats after the detraining period. Int. J. Morphol., 36(4):1341-1349, 2018.

dominal fat and intrahepatic lipids in obese people, decreasing the concentration of adiponectin and of the adiponectin/leptin ratio, subcutaneous fat, LDL, total cholesterol and in the amount of alanine aminotransferases (Lee et al., 2012).

However, it is indicated that the therapeutic conduct involving intermittent training must be practiced regularly to avoid the detraining condition, defined as the interruption of the, so far, regularly practiced physical training, when the benefits generated by the exercise are partially or totally lost (Kim et al., 2013).

The literature available lacks perspicuity regarding the effect of intermittent training followed by detraining on the body composition and hepatic tissue of eutrophic and obese rats, also considering the possible clinical aspects that may support new approaches for patients during the treatment of obesity and its comorbidities. Therefore, this study aims to evaluate the effect of an intermittent training program followed by detraining on the body composition and the liver tissue of rats subjected to a normolipidic or hyperlipidic diet.

\section{MATERIAL AND METHOD}

Animals. Sixty male Wistar rats (each 60 days old) were obtained and kept in shared plastic cages, groups of three animals per cage, in the vivarium under average temperature of $22 \pm 2{ }^{\circ} \mathrm{C}$ and light/dark cycles of $12 \mathrm{~h}$, with the light cycle commencing at $7 \mathrm{~h}$, and fed standard feed and tap water, provided ad libitum. The animals body mass was taken three times a week, throughout the experimental period.

All procedures followed the Ethical Principles in Animal Experimentation adopted by the Brazilian Society of Science in Laboratory Animals (SBCAL). This study was approved by the Ethics in Animal Research Committee (CEUAS) from FCT/UNESP, filed under $n^{\circ}$ 004/2011. The 60 animals were randomly assigned, distributed as follows:

Initially, Control and Obese groups were each divided into two subgroups: Sedentary Control (SC, $n=10)$, Exercised Control (EC, $\mathrm{n}=20)$, Sedentary Obese $(\mathrm{SO}, \mathrm{n}=10)$ and Exercised Obese (EO, $\mathrm{n}=20$ ). The groups $\mathrm{SC}$ and $\mathrm{SO}$ were divided once again in two subgroups: Sedentary Control (SC, $\mathrm{n}=5$ ), Sedentary Control euthanized at six months of age $(\mathrm{SC}(6), \mathrm{n}=5)$; Sedentary Obese $(\mathrm{SO}, \mathrm{n}=5)$, Sedentary Obese euthanized at six months of age $(\mathrm{SO}(6), \mathrm{n}=5)$.

Within the EC and EO groups the same subdivisions also occurred: Exercised Control (EC, $\mathrm{n}=10)$, Detrained
Control ( $\mathrm{CD}, \mathrm{n}=10)$; Exercised Obese (EO, $\mathrm{n}=10)$, Detrained Obese (DO, $\mathrm{n}=10$ ) (Fig. 1). This division in the groups was made because the groups $\mathrm{SC}, \mathrm{EC}, \mathrm{SO}$ and $\mathrm{EO}$ were euthanized after the intermittent training protocol period, 60 days after the experiment began, while groups $\mathrm{SC}(6), \mathrm{DC}, \mathrm{SO}(6)$ and DO were euthanized after the detraining protocol period, 120 days after the experiment began.

The animals from the groups SC, EC, DC and SC(6) were fed standard feed (Labina feed, from the brand Purina $\left.{ }^{\circledR}\right)$, provided with tap water ad libitum. The groups $\mathrm{SO}, \mathrm{EO}, \mathrm{DO}$ and $\mathrm{SO}(6)$ followed a hyperlipidic diet (cafeteria diet) (Lamas et al., 2004; Panveloski-Costa et al., 2011) which consisted of: bacon, bologna, sausage, cookies, soda and standard feed, on a ratio of $2: 2: 2: 1: 1: 1$, respectively, in a composition of $28 \%$ carbohydrate, $13 \%$ protein and 59 $\%$ fat by the start of the training protocol, provided ad libitum and tap water ad libitum, resupplied every day.

\section{Intermittent training}

Training Model. The intermittent training was the "Jump Squat" model (Tamaki et al., 1992). The device allowed the animal to be placed on a metal platform while immobilized by a fitted vest. The jumps were performed by an electrical stimulation from a metallic clip attached to the tail end of the animal and connected to a Dualpex type stimulator 961, the Quarker $^{\circledR}$, with a frequency of $1 \mathrm{Hertz}(\mathrm{Hz})$ and duration of $0.3 \mathrm{~s}$, with $2 \mathrm{~s}$ intervals between each electrical stimulation and a charge ranging from 3 to 6 milliamperes (mA) (Fig. 2).

With this stimulation, the animals underwent the full movement extent of the leg (knee and ankle), lifting a load that was placed on the posterior part of the vest. The movement "jump squat" was tested and validated as an inducer of hypertrophy in animals, similar to the hypertrophy obtained in human weightlifters (Tamaki et al., 1997).

The training protocol was composed of three sets of 12 repetitions, with an interval of $60 \mathrm{~s}$ between sets and performed three times a week, with an interval of $24 \mathrm{~h}$ between each day of training, for a period of 60 days.

Three preliminary sessions were performed for adaptation to the training in the first two weeks, during which the animals underwent training without load increase. From the third week, a load equivalent to $50 \%$ of the body mass of the animal was imposed for all experimental period, with adjustments or overload according to the variations of the weight of each animal. This training protocol was initiated in combination with a hyperlipidic diet when the animals reached 60 days old. 


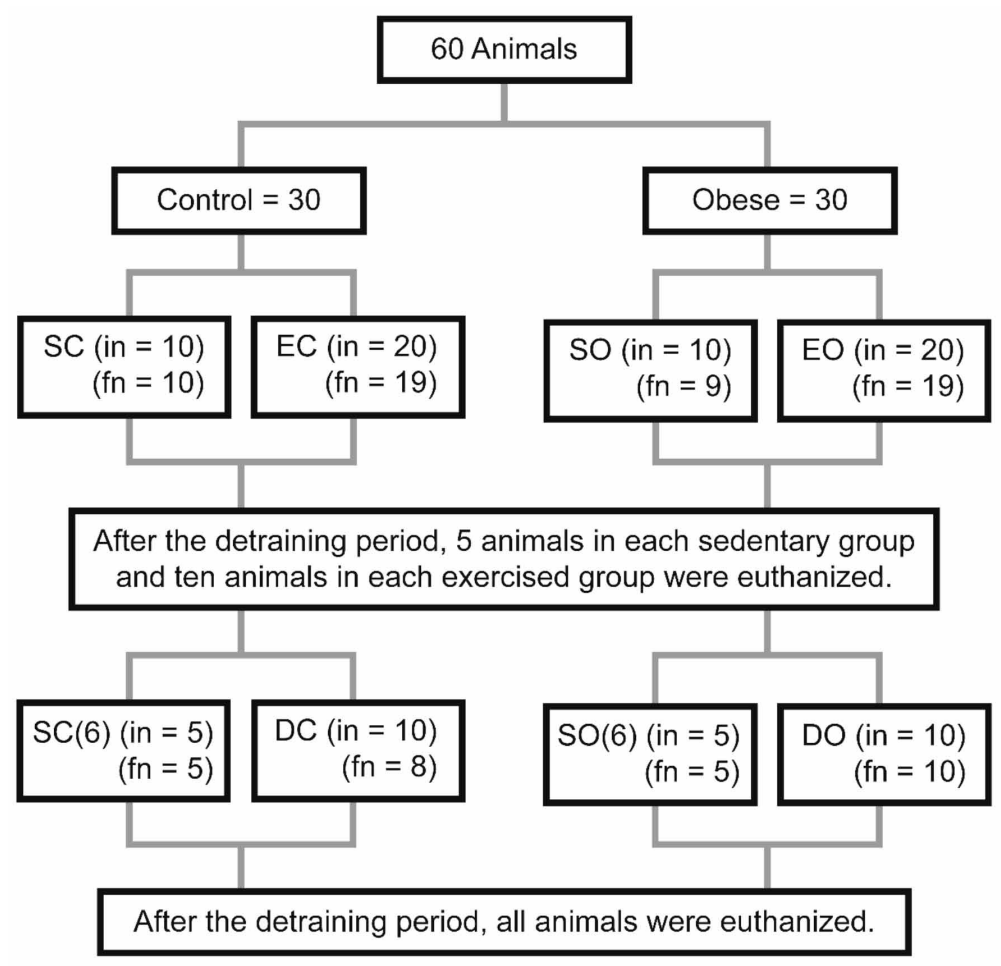

Fig. 1. Experimental design module. Legend: $\mathrm{SC}=$ Sedentary Control; $\mathrm{EC}=$ Exercised Control; $\mathrm{SC}(6)=$ Sedentary Control euthanized at six months of age; $\mathrm{DC}=$ Detrained Control; $\mathrm{SO}=$ Sedentary Obese; $\mathrm{EO}=$ Exercised Obese; $\mathrm{SO}(6)$ $=$ Sedentary Obese euthanized at six months of age; $\mathrm{DO}=$ Detrained Obese.; in $=$ initial number; $\mathrm{fn}=$ final number.

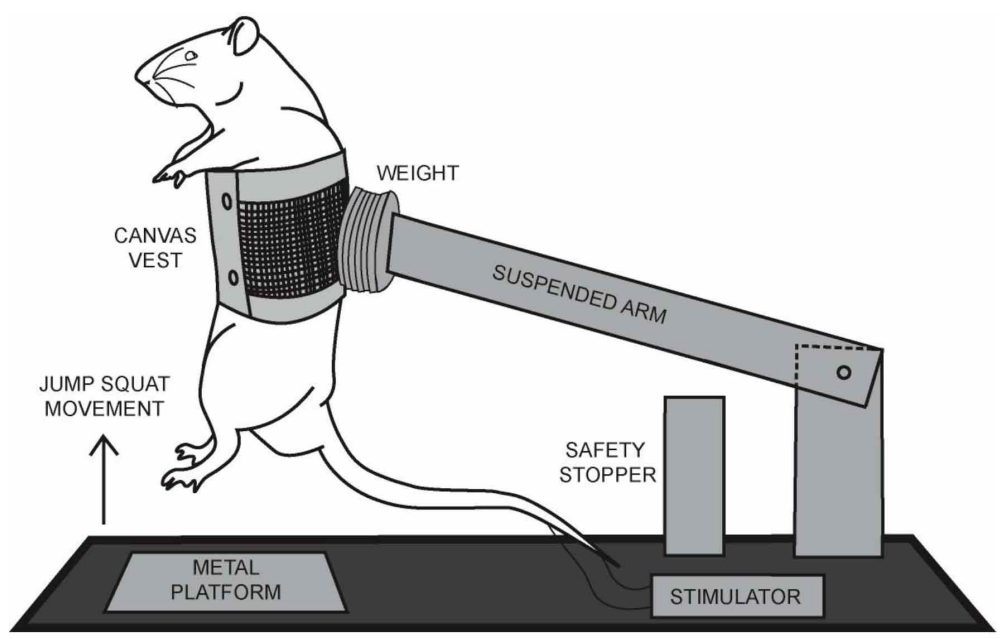

Fig. 2. Representative diagram of the device used for training jump squats, adapted from Panveloski-Costa et al. (2011).

At the end of the training protocol began the detraining period for the animals from the groups DC and DO, in which the animals were kept for 60 days without performing any physical training. The animals from the $\mathrm{SC}(6)$ and $\mathrm{SO}(6)$ remained without performing any physical activity. The respective diets of each group were not changed.
Surgical procedure. The animals of the groups SC, EC, SO and EO were euthanized $24 \mathrm{~h}$ after the last intermittent training session. The animals of the groups $\mathrm{SC}(6), \mathrm{DC}, \mathrm{SO}(6)$ and DO were euthanized $24 \mathrm{~h}$ after the last day of detraining protocol. The animals had their length and body mass measured to calculate the body mass gain (DM = final mass - initial mass). Then, a paramedian incision was made in the abdomen, folding the epithelial tissue for the exposure of the organs. Soon after the incision, the epididymal adipose tissue was removed and weighed on a precision weighing scale.

The animals' hepatic tissue was also extracted and weighed on precision weighing scale. In all animals, only the right upper lobe of their livers was standardized for analysis and fixed in a $10 \%$ formalin solution. Twenty-four $\mathrm{h}$ after the extraction of the liver's right upper lobe, this part of the organ was transferred to vials with alcohol $70 \%$. This solution was replenished for three days, resulting in the subsequent removal of formalin residue (Camargo Filho et al., 2011).

\section{Body Composition Assessment}

Lee Index. The Lee Index was calculated in all animals using the relation between the cube root of body mass ( $\mathrm{g}$ ) divided by the snout-rump length $(\mathrm{cm})$ and multiplied by 10 (Novelli et al., 2007).

Body Mass Index. The Body Mass Index (BMI) was calculated by: Body Mass (g) / [snout-rump Length $\left.(\mathrm{mm}) \sum\right]$ (Sjögren et al., 2001).

Epididymal Adipose Tissue (EAT). After extraction, the epididymal adipose tissue (EAT) was weighed on a precision weighing scale. For the data analysis, both the percentage and total value of the tissue relative to the mass of each animal were determined by: $\{[\operatorname{EAT}(\mathrm{g}) \times 100]$ / Body Mass $(\mathrm{g})\}$. This procedure was established as a way of correcting the difference in body mass between the animals (Shi et al., 2007).

\section{Liver Tissue Evaluation}

Tissue Morphology. After the fixation and permanence in alcohol $70 \%$, a procedure for the inclusion of the material in paraffin was 

preservation of hepatic tissue and body composition of eutrophic rats in relation to obese rats after the detraining period. Int. J. Morphol., 36(4):1341-1349, 2018.

carried out, as well as the microtomy in the rotary microtome Microm ${ }^{\circledR}$ HM 325, which performed transversal cuts $6 \mathrm{~mm}$ thick. The staining was performed by associating two stains: Hematoxylin and Eosin (HE) (Dal Pai, 1995). The HE-stained slides were used for kariometric and stereological analysis of the liver tissue.

Kariometry and Stereology of the Liver Tissue. The images of the liver tissue of animals were obtained through a Nikon ${ }^{\circledR} 50 \mathrm{i}$ optical microscope, with 1000x magnification and the coupling of a Nikon ${ }^{\circledR}$ Infinity 1 digital camera and the images were captured using the computer image analysis software NIS-Elements D 3.0 - SP7 - build 547, Nikon® ${ }^{\circledR}$ for Windows ${ }^{\circledR}$.

The kariometric analysis (Martins et al., 2010) was performed using the computer image analysis software Image-Pro Plus 4.5.0.29 For Windows ${ }^{\circledR}$ 98-NT-2000, Media Cybernetics Inc. In the images obtained were accounted 100 nuclei of the hepatocytes of each animal, in which two lines were traced, one on the largest diameter (major diameter (D)) and the other on the smallest diameter (minor diameter (d)) of each nucleus. Soon after, these values were put into equations by providing the kariometric parameters.

For the stereological study (Martins et al.) 20 images of each component group were obtained and the areas for analysis were delimited, using the computer image analysis software Image ${ }^{\circledR} 1.47 \mathrm{t}$ for Windows ${ }^{\circledR}$ the National Institute of Health - USA (Fig. 3). The only counted testpoints were the ones that touched the cellular structure of the hepatocytes, within an area. This counting system of test-points was performed in the cytoplasm, nucleus and extracellular matrix of the hepatocytes. The projection was performed in 20 different test-areas, with 100 points for each test-area, and a total of 2000 points per animal group. After these procedures, these values were put into equations and the stereological parameters was obtained (Figs. 4 and 5).

The unit of measurement used for the values was the micrometer $(\mu \mathrm{m})$. The calculations was made using the computer software Excel $2013^{\circledR}$ from Microsoft Office $2013^{\circledR}$ for Windows ${ }^{\circledast}$.

Statistical Analysis. For statistical comparison of the body composition, kariometric and stereological results between groups, the Levene's test was used to verify the normality of the data, the ANOVA One Way test and the Tukey's posttest were used for parametric data and the Kruskal-Wallis' test and the Dunn's post-test were used for non-parametric data. All procedures adopted the significance level of $(p<0,05)$. The calculations were performed with the $R$ version 3.5.2 software for Windows ${ }^{\circledR}$ and the Origin version $9.0^{\circledR}$ software for Windows ${ }^{\circledR}$ was utilized for the elaboration of charts.

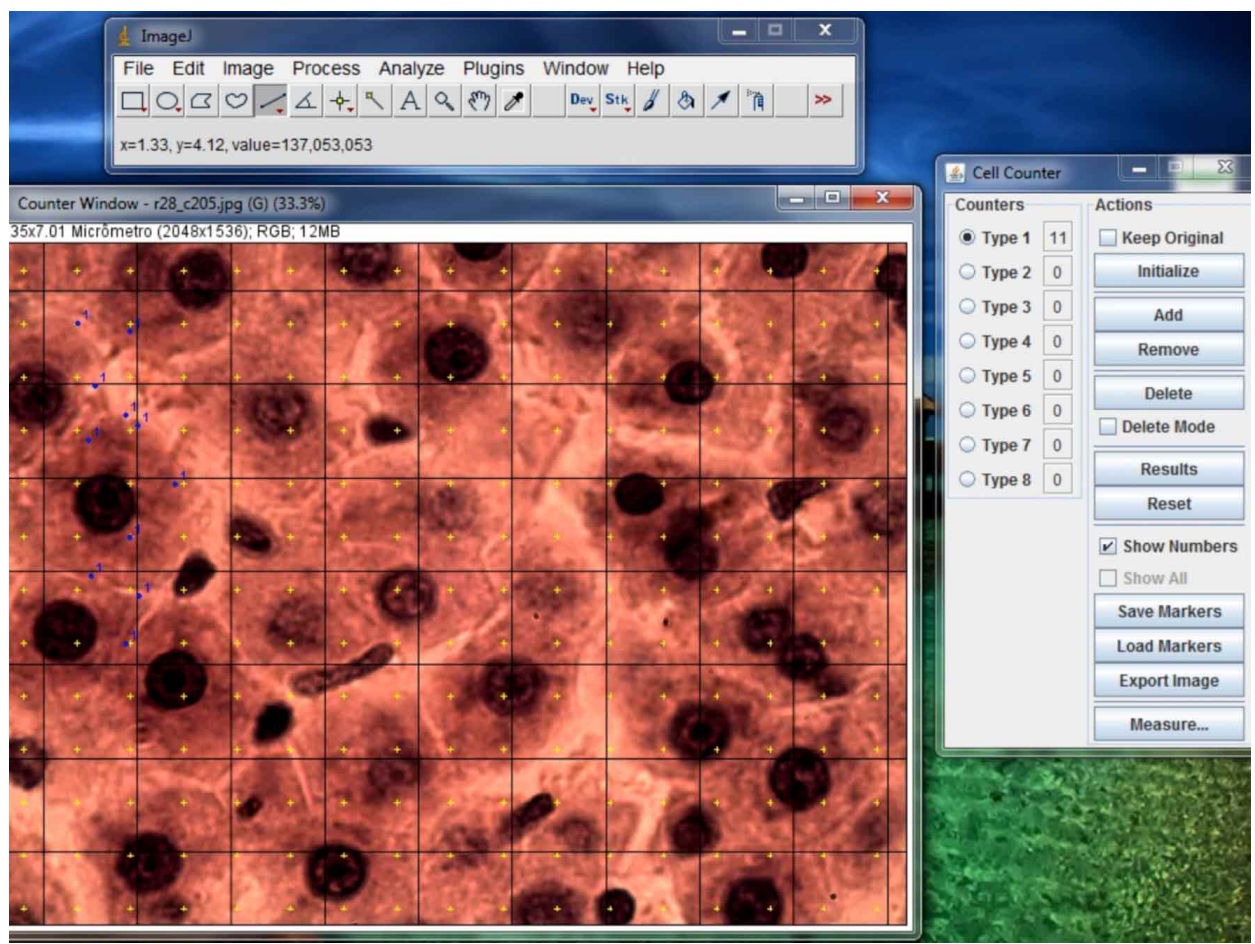

Fig. 3. Usage of the software Image ${ }^{\circledR} 1.47 \mathrm{t}$ for Windows ${ }^{\circledR}$ the National Institute of Health - USA. 

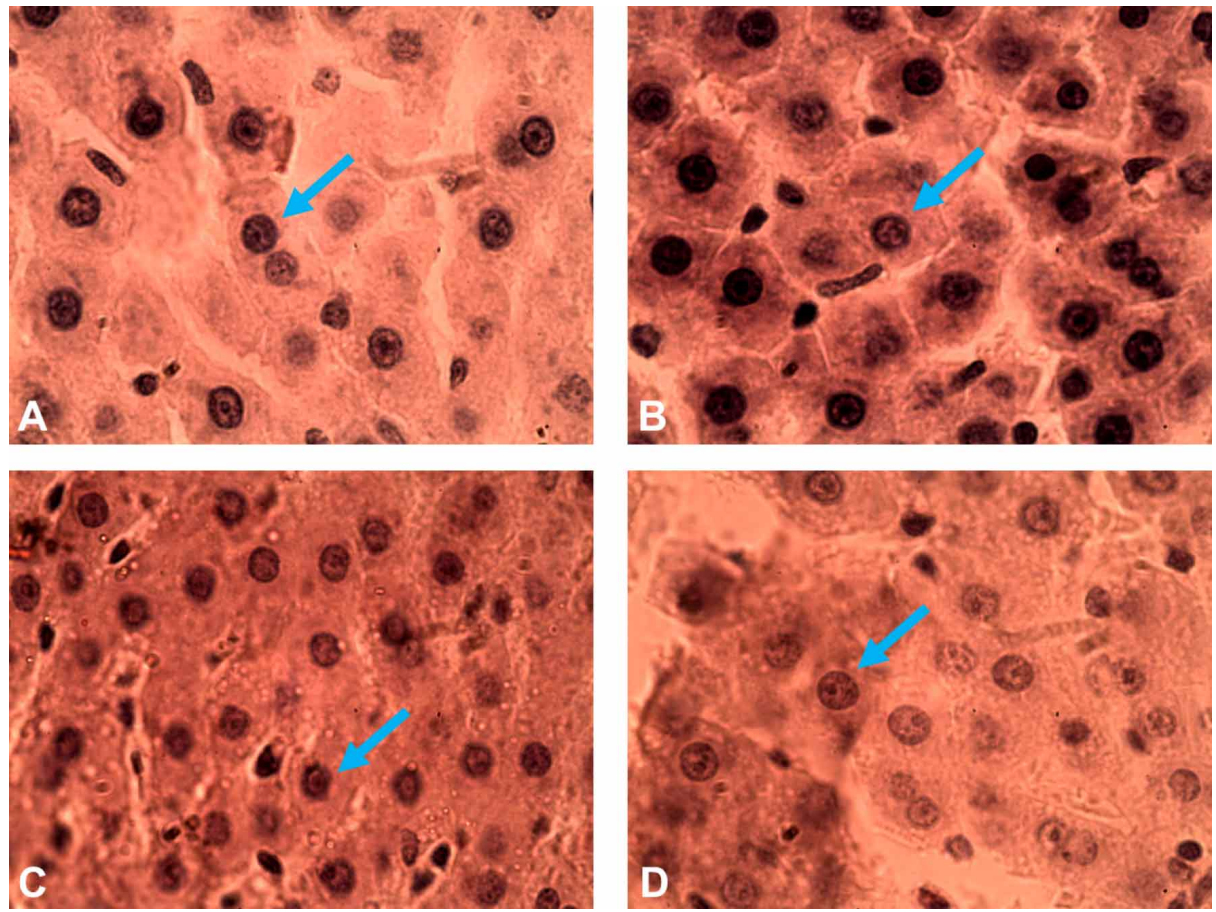

Fig. 4. Photomicrography of the liver tissue of the rats, cut with a thickness of $6 \mu \mathrm{m}$ and stained by $\mathrm{H}-\mathrm{E}$. The arrows point to the nuclei of the hepatocytes. Legend: $\mathrm{A}=$ group $\mathrm{SC} ; \mathrm{B}=$ group $\mathrm{EC} ; \mathrm{C}=$ group SC(6); D= group DC. 1000x.
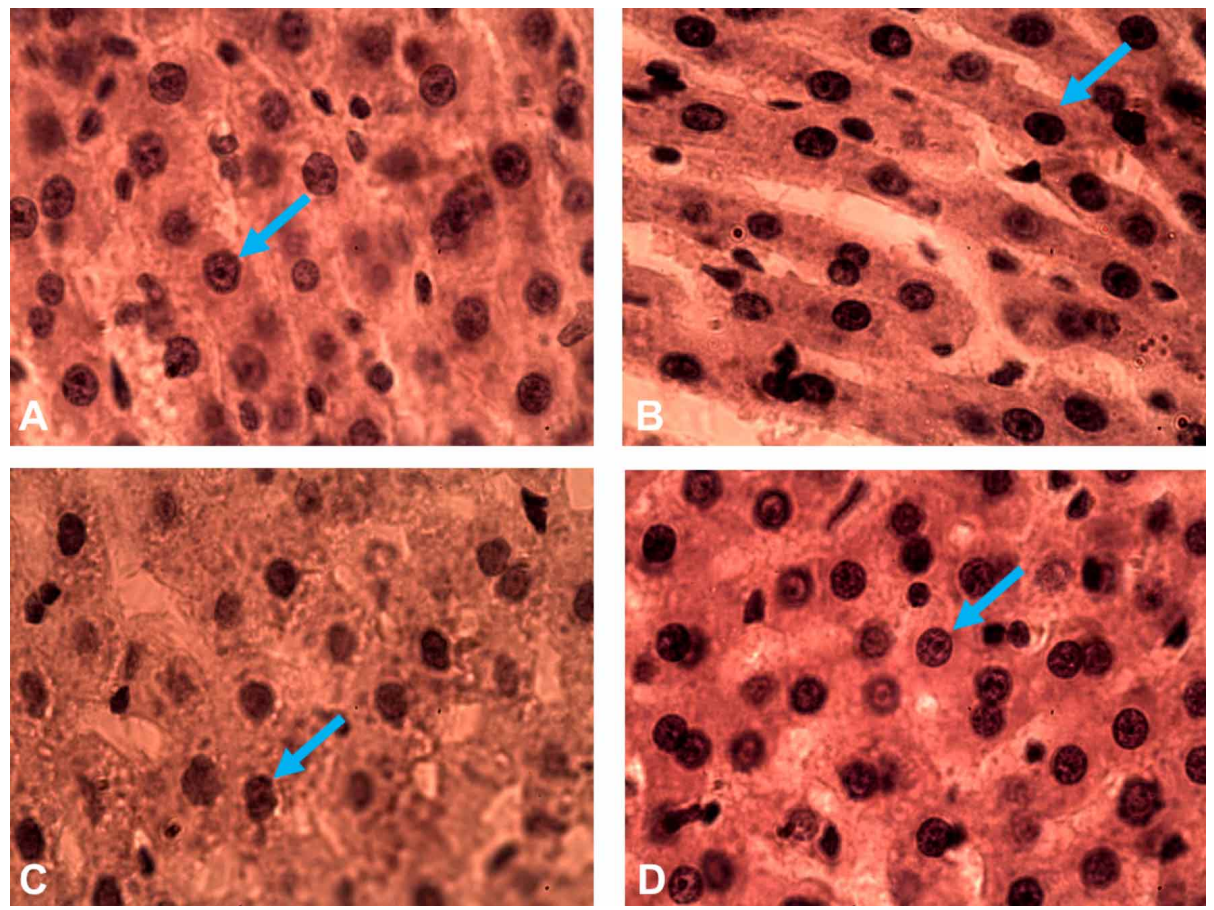

Fig. 5. Photomicrography of the liver tissue of the rats, cut with a thickness of $6 \mu \mathrm{m}$ and stained by $\mathrm{H}-\mathrm{E}$. The arrows point to the nuclei of the hepatocytes. Legend: $\mathrm{A}=$ group $\mathrm{SO} ; \mathrm{B}=$ group $\mathrm{EO} ; \mathrm{C}=$ group $\mathrm{SO}(6)$; $\mathrm{D}=$ group DO. 1000x.

\section{RESULTS}

Figure 6 shows the values of body mass gain of the studied groups on 2nd, 4th and 6th Month's age of the animals during the experiment (start, middle and end, respectively).

Statistically significant difference can be seen in body mass gain value of the $\mathrm{SO}(6)$ in comparison to $\mathrm{EC}(\mathrm{p}=0,04)$.

Table I shows the values for body composition and liver mass (LM) of all groups.

It was possible to see in Table I statistically significant differences $(p<0.05)$ in the variable EAT ( $\mathrm{g}$ ) of the EC and DC compared to $\mathrm{SO}(6)$ and $\mathrm{DO}$; in the EAT (\%) of DC compared to $\mathrm{SO}(6)$ and $\mathrm{DO}$; in the $\mathrm{BMI}$ of EC compared to $\mathrm{SO}(6)$ and DO; and in the LM between EC and $\mathrm{DO}$, and between $\mathrm{SO}(6)$ and all other groups.

The kariometric values of the nuclei of the hepatocytes of all the groups are found in Table II.

In Table II, we can observe significant differences $(\mathrm{p}<0.05)$ between DC, EO and DO in the variables minor diameter, mean diameter, D/d, volume, area, shape coefficient and contour index.

The stereological values for liver tissue of all the groups are found in Table III.

In Table III, there were no statistical differences between the stereological variables found among the groups studied. 


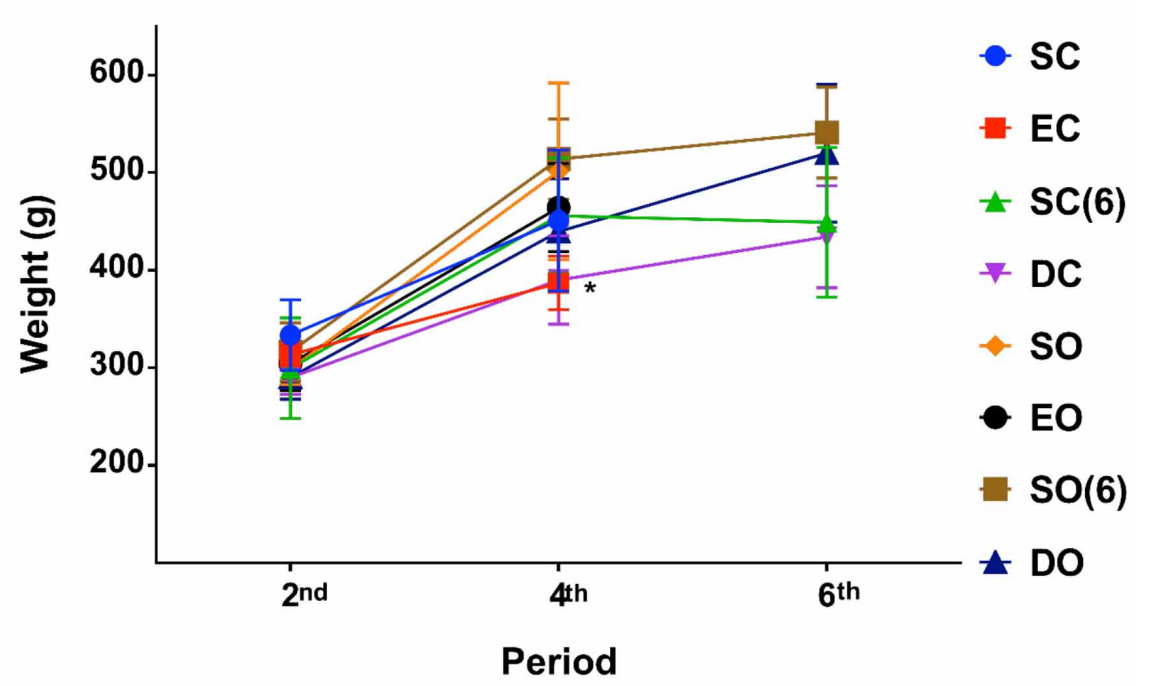

Fig. 6. Evolution of the animals body mass during the experiment. Legend: $\mathrm{SC}=$ Sedentary Control; EC = Exercised Control; $\mathrm{SC}(6)=$ Sedentary Control euthanized at six months of age; $\mathrm{DC}=$ Detrained Control; $\mathrm{SO}=$ Sedentary Obese; $\mathrm{EO}=$ Exercised Obese; $\mathrm{SO}(6)=$ Sedentary Obese euthanized at six months of age; DO = Detrained Obese; 2nd, 4th and 6th $=$ Month's age of the animals during the experiment (start, middle and end, respectively). The ANOVA One Way and the Tukey's post-test (Mean \pm Standard Deviation) were used for the comparison of the results. Significance values $p<0.05$ were adopted for all procedures. * Statistically significant difference in the mass gain of the EC compared to the $\mathrm{SO}(6)$.

\section{DISCUSSION}

The main results of this study regarding the body composition of the groups were: lower body mass gain of EC compared to the SO(6); lower amount of EAT (g) in EC and $\mathrm{DC}$ in relation to $\mathrm{SO}(6)$ and DO; lower EAT (\%) in DC compared to $\mathrm{SO}(6)$ and $\mathrm{DO}$; lower $\mathrm{BMI}$ in $\mathrm{EC}$ compared to $\mathrm{SO}(6)$ and $\mathrm{DO}$.

A study suggests that intermittent training can positively affect inflammation parameters, body mass, adipocyte areas and lipids concentration in mice (Speretta et al., 2012). In addition to the regular training, calorie intake restriction can contribute to the increase of systemic glucose tolerance, improve mitochondrial fatty acid oxidation and oxidative function of enzymes and suppress hepatic lipogenesis (Rector et al., 2011).

Such parameters corroborate the results of our study, the EC had lower body mass gain compared to the $\mathrm{SO}(6)$, in addition to the lower values of body composition, particularly the $\mathrm{EC}$ and $\mathrm{DC}$ in comparison to the $\mathrm{SO}(6)$ and the $\mathrm{DO}$. Also, the values of body composition of DC do not show significantly difference from EC, which can indicate that the detraining did not reflect any type of influence on the effects initially provided by the intermittent training.

In regards to the $\mathrm{LM}$, animals receiving a hyperlipidic diet have higher gain in body mass, an increase in adiposity and IHTG (Leite et al., 2013). These variables may have influenced the increase in liver mass of $\mathrm{SO}(6)$ in relation to all groups, and of DO compared to EC.
As for the kariometric analysis of liver tissue, the main findings were that the animals of the DC had the nuclei of their hepatocytes with greater size and volume, and less deformation in comparison to animals of the $\mathrm{SO}(6)$ and $\mathrm{DO}$. As for the stereological analysis, there were no significant differences between groups.

Nuclear size and shape changes in liver tissue of animals exposed to toxic substances are considered a phenomenon known as anisonucleosis, associated with the presence of immunomarkers of oxidative damage in the liver, which may point to an inflammatory process in the liver tissue (Jarrar \& Taib, 2012).

A hyperlipidic diet may induce a decrease in size and change in the conformation of the nucleus of the hepatocytes of the animals. The hydropic degeneration, which occurs in the liver tissue of obese animals according to inflammatory processes generated by a macrovesicular steatosis, contributes to the anisonucleosis of the nucleus of hepatocytes (Accioly et al., 2013). The hepatocytes from $\mathrm{SO}(6)$ and DO are more exposed to the risk of increased IHTG concentration compared to DC.

A study found that the use of a hyperlipidic diet may affect the pathophysiology of NAFLD, since the excess saturated fat and fructose contained in food may stimulate the accumulation of IHTG, aggravating the hepatic steatosis (Berglund et al., 2011). This same study also shows that changes in the type of diet used may provide a preventive 

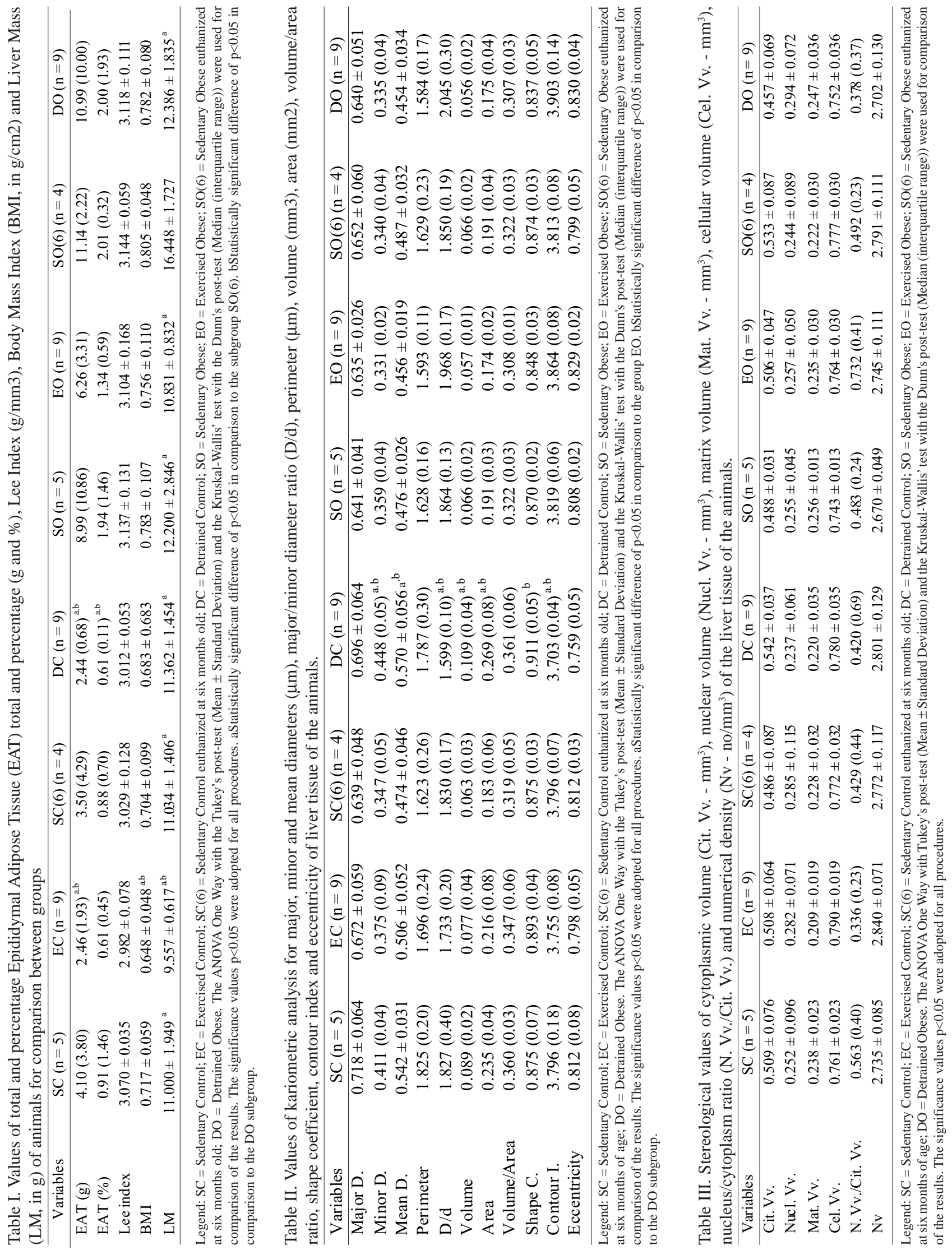
MAGALHÃES, A. J. B.; CAMARGO, R. C. T.; MOREIRA, R. J.; SERAPHIM, P. M.; OIKAWA, S. M. \& CAMARGO FILHO, J. C. S. Intermittent training followed by detraining provides the preservation of hepatic tissue and body composition of eutrophic rats in relation to obese rats after the detraining period. Int. J. Morphol., 36(4):1341-1349, 2018.

effect against NAFLD. This suggests that the diet may be an important variable in the development of NAFLD, and that less consumption of hyperlipidic diets may reduce the content of IHTG, thereby reducing its deleterious effects on the liver tissue.

Besides that, the addition of an intermittent training protocol minimizes the deleterious effects provided by a hyperlipidic diet consumption (Leite et al.). This occurs as a result of the increased activity of superoxide dismutase and catalase in the hepatic tissue of animals that underwent intermittent training, improving the effectiveness of the antioxidant system, thus reducing the markers of liver peroxidation (Botezelli et al., 2011).

The intermittent training results in the decrease of lipid content of EAT, serum lipid profile and decrease in IHTG in animals. Furthermore, the intermittent training can stimulate the release of hepatic glucagon through metabolic pathways, contributing to the reversal of fatty liver condition in rats (de Wit et al., 2012).

A combined intervention with intermittent training and a normolipidic diet can reduce the concentration of IHTG, serum leptin and of the size of adipose cells and may reflect in the reduction of body mass and also reduction of apoptosis markers in the liver tissue cells, avoiding liver tissue damage caused by IHTG (Kurosaka et al., 2015).

Therefore, the use of the normolipid diet in addition to intermittent training may have been an important factor why the animals in the EC and DC groups presented lower values of body composition compared to the animals of the $\mathrm{SO}(6)$ and DO groups, as well as for the animals in the DC group presented greater preservation effect on the hepatic tissue in relation to EO and DO.

This study analyzed the liver condition only by images, besides evaluating the body composition using EAT and variables derived from the length and body mass of the animals. Based on what has been presented, this study has some suggestions for future researches. It would be interesting to quantify the amount of intrahepatic fat and verify if this is a determining factor for the difference in LM of the obese groups mentioned. It would also be valid to compare the performance of other training protocols implemented in isolation and together with intermittent training, to calculate the food coefficient of the animals and to analyze the concentration of antiinflammatory and proinflammatory cytokines, considering the effects of both types on the accumulation of lipids found in obesity and in NAFLD.
We conclude that the intermittent training showed better effects on the DC liver tissue relative to the EO and DO, and it showed better effects on the body composition of the EC and DC in relation to the $\mathrm{SO}(6)$ and DO. Detraining have no significant effects on intermittent training.

\section{ACKNOWLEDGMENTS}

We thank the Coordenação de Aperfeiçoamento de Pessoal de Nível Superior-CAPES for the financial support in the development of this study. The authors declare no conflict of interest in this work.

MAGALHÃES, A. J. B.; CAMARGO, R. C. T.; MOREIRA, R. J.; SERAPHIM, P. M.; OIKAWA, S. M. \& CAMARGO FILHO, J. C. S. El entrenamiento intermitente seguido de desacondicionamiento facilita la preservación del tejido hepático y la composición corporal de las ratas eutróficas en relación a las ratas obesas después del período de desacondicionamiento. Int. J. Morphol., 36(4):1341-1349, 2018.

RESUMEN: El objetivo del estudio fue evaluar los efectos del entrenamiento intermitente seguido de desentrenamiento en el tejido hepático y la composición corporal de ratas sometidas a una dieta normolipídica e hiperlipídica. Sesenta ratas Wistar se dividieron en los siguientes grupos: Control Sedentario (CS), Control Entrenado (CE), Control Sedentario sacrificado a los seis meses de edad (SC (6)), Control Desentrenado (CD), Obeso Sedentario (OS), Obeso Entrenado (OE), Obesidad Sedentaria sacrificados a los seis meses de edad (OS) (6)) y Obesidad Desentrenada (DOD), que realizó un entrenamiento intermitente durante ocho semanas. Posteriormente, los grupos CS (6), CD, OS (6) y DO realizaron un protocolo de desentrenamiento durante ocho semanas. Los animales fueron sacrificados, con mediciones de masa corporal y longitud, y la recuperación de tejido adiposo epididimal (EAT) para las variables de composición corporal y el hígado para el análisis estereológico y cariométrico. Se encontraron diferencias significativas en los valores de la masa hepática de CE en relación con DO y en el hígado SO (6) en relación con todos los grupos, con un mayor aumento en la masa corporal del SO (6) en comparación con la CE; en el total de EAT, porcentaje de EAT y BM de SO (6) y OD en relación con $\mathrm{CE}$ y $\mathrm{CD}$ y en las variables cariométricas de $\mathrm{CE}$ y $\mathrm{CD}$ en relación con OE y OD, sin diferencias en la estereología y en el índice de Lee entre todos los grupos. En el entrenamiento intermitente se observaron mejores efectos en el tejido hepático de CD en comparación con OE y OD, y en la composición corporal de CE y CD en comparación con OS (6) y OD.

PALABRAS CLAVE: Obesidad; Hígado; Composición corporal; Ejercicio; Histología. 


\section{REFERENCES}

Accioly, M. F.; Souza, D. R. S.; Padulla, S. A. T.; Camargo Filho, J. C. S.; do Carmo, E. M.; Martins, A. T.; Brandão, A. C. \& Azoubel, R. Effect of statins and aerobic physical exercise on liver function in dyslipidemic rats - Morphometric study. Int. J. Morphol., 31(4):1309-16, 2013.

Assaad, H.; Yao, K.; Tekwe, C. D.; Feng, S.; Bazer, F. W.; Zhou, L.; Carroll, R. J.; Meininger, C. J. \& Wu, G. Analysis of energy expenditure in diet-induced obese rats. Front. Biosci. (Landmark Ed), 19:967-85, 2014.

Berglund, E. D.; Lustig, D. G.; Baheza, R. A.; Hasenour, C. M.; Lee-Young, R. S.; Donahue, E. P.; Lynes, S. E.; Swift, L. L.; Charron, M. J.; Damon, B. M. \& Wasserman, D. H. Hepatic glucagon action is essential for exercise-induced reversal of mouse fatty liver. Diabetes, 60(11):27209, 2011.

Botezelli, J. D.; Cambri, L. T.; Ghezzi, A. C.; Dalia, R. A.; Scarioti, P. P. M.; Ribeiro, C.; Voltarelli, F. A. \& Mello, M. A. Different exercise protocols improve metabolic syndrome markers, tissue triglycerides content and antioxidant status in rats. Diabetol. Metab. Syndr., 3:35, 2011.

Camargo Filho, J. C. S.; Garcia, B. C.; Kodama, F. Y.; Bonfim, M. R.; Vanderlei, L. C. M.; Ramos, E. M. C.; Camargo, R. C. T.; Padulla, S. A. T. \& Maeda, J. K. Effects of Aerobic Exercise on the Skeletal Muscle of Rats Exposed to Cigarette Smoke. Rev. Bras. Med. Esporte, 17(6):416-9, 2011

Dal Pai, V. Histoenzimologia: Teoria e Prática. Instituto de Biociências. Botucatu, Universidade Estadual Paulista, 1995.

de Wit, N. J.; Afman, L. A.; Mensink, M. \& Müller, M. Phenotyping the effect of diet on non-alcoholic fatty liver disease. J. Hepatol., 57(6):1370-3, 2012.

Jarrar, B. M. \& Taib, N. T. Histological and histochemical alterations in the liver induced by lead chronic toxicity. Saudi J. Biol. Sci., 19(2):20310, 2012.

Kim, D.; Singh, H.; Young, K. C.; Fahs, C. A.; Rossow, L. M.; Loenneke, J. P.; Thiebaud, R. S.; Kim, E.; Ye, X.; Bemben, D. A. \& Bemben, M. G. Effects of detraining on performance measures following cycling with or without blood flow restriction. Med. Sci. Sports Exerc., 2013; 45(5):616-616.

Kurosaka, Y.; Shiroya, Y.; Yamauchi, H.; Kaneko, T.; Okubo, Y.; Shibuya, K. \& Minato, K. Effects of habitual exercise and dietary restriction on intrahepatic and periepididymal fat accumulation in Zucker fatty rats. B. M. C. Res. Notes, 8:121, 2015.

Lamas, O.; Martínez, J. A. \& Marti, A. Energy restriction restores the impaired immune response in overweight (cafeteria) rats. J. Nutr. Biochem., 15(7):418-25, 2004.

Lee, S.; Bacha, F.; Hannon, T.; Kuk, J. L.; Boesch, C. \& Arslanian, S. Effects of aerobic versus resistance exercise without caloric restriction on abdominal fat, intrahepatic lipid, and insulin sensitivity in obese adolescent boys. A randomized, controlled trial. Diabetes, 61(11):278795, 2012.

Leite, R. D.; Durigan, R. de C.; de Souza Lino, A. D.; de Souza Campos, M. V.; Souza, M. D.; Selistre-de-Araújo, H. S.; Bouskela, E. \& KraemerAguiar, L. G. Resistance training may concomitantly benefit body composition, blood pressure and muscle MMP-2 activity on the left ventricle of high-fat fed diet rats. Metabolism, 62(10):1477-84, 2013.

Martins, A. T.; Santos, F. S.; Scannavino, L. F. L.; Pires, J. R.; Zuza, E. P.; Junior, J. A. P.; Azoubel, R.; Di Mateo, M. A. S. \& Lopes, R. A. Effect of sodium cyclamate on the rat fetal exocrine pancreas: a karyometric and stereological study. Int. J. Morphol., 28(3):899-904, 2010.

Novelli, E. L.; Diniz, Y. S.; Galhardi, C. M.; Ebaid, G. M.; Rodrigues, H. G.; Mani, F.; Fernandes, A. A.; Cicogna, A. C. \& Novelli Filho, J. L. Anthropometrical parameters and markers of obesity in rats. Lab. Anim., 41(1):111-9, 2007.

Panveloski-Costa, A. C.; Pinto Júnior, D. A.; Brandão, B. B.; Moreira, R. J.; Machado, U. F. \& Seraphim, P. M. Resistive training reduces inflammation in skeletal muscle and improves the peripheral insulin sensitivity in obese rats induced by hyperlipidic diet. Arq. Bras. Endocrinol. Metabol., 55(2):155-63, 2011.

Rector, R. S.; Uptergrove, G. M.; Morris, E. M.; Borengasser, S. J.; Laughlin, M. H.; Booth, F. W.; Thyfault, J. P. \& Ibdah, J. A. Daily exercise vs. caloric restriction for prevention of nonalcoholic fatty liver disease in the OLETF rat model. Am. J. Physiol. Gastrointest. Liver Physiol., 300(5):G874-83, 2011.

Shi, H.; Strader, A. D.; Woods, S. C. \& Seeley, R. J. The effect of fat removal on glucose tolerance is depot specific in male and female mice. Am. J. Physiol. Endocrinol. Metab., 293(4):E1012-20, 2007.

Sjögren, K.; Hellberg, N.; Bohlooly-Y, M.; Savendahl, L.; Johansson, M. S.; Berglindh, T.; Bosaeus, I. \& Ohlsson, C. Body fat content can be predicted in vivo in mice using a modified dual-energy $\mathrm{X}$-ray absorptiometry technique. J. Nutr., 131(11):2963-6, 2001.

Song, Y.; Lee, S. J.; Jang, S. H.; Ha, J. H.; Song, Y. M.; Ko, Y. G.; Kim, H. D.; Min, W.; Kang, S. N. \& Cho, J. H. Sasa borealis stem extract attenuates hepatic steatosis in high-fat diet-induced obese rats. Nutrients, 6(6):2179-95, 2014.

Spassiani, N. A. \& Kuk, J. L. Exercise and the fatty liver. Appl. Physiol. Nutr. Metab., 33(4):802-7, 2008.

Speretta, G. F.; Rosante, M. S.; Duarte, F. O.; Leite, R. D.; Lino, A. D.; Andre, R. A.; Silvestre, J. G.; Araujo, H. S. \& Duarte, A. C. The effects of exercise modalities on adiposity in obese rats. Clinics (Sao Paulo), 67(12):1469-77, 2012.

Tamaki, T.; Akatsuka, A.; Tokunaga, M.; Ishige, K.; Uchiyama, S. \& Shiraishi, T. Morphological and biochemical evidence of muscle hyperplasia following weight-lifting exercise in rats. Am. J. Physiol., 273(1 Pt. 1):C246-56, 1997.

Tamaki, T.; Uchiyama, S. \& Nakano, S. A weight-lifting exercise model for inducing hypertrophy in the hindlimb muscles of rats. Med. Sci. Sports Exerc., 24(8):881-6, 1992.

\section{Corresponding author: \\ Alan José Barbosa Magalhães \\ Rua Roberto Simonsen, 305, Centro Educacional \\ Presidente Prudente - SP \\ BRASIL}

Email: ajb_magalhaes@yahoo.com.br

Received: 28-05-2018

Accepted: 06-08-2018 